\title{
Assessment of the Symptoms of Premenstrual Syndrome in Physically Active and Sedentary Adult Women
}

\author{
Luisa Muller Arruda ${ }^{1}$, Luana Selaimen Martins ${ }^{2}$ and Thaís Rodrigues Moreira ${ }^{3,{ }^{*}}$
}

${ }^{1}$ Nutritionist at Univates University Center, Specialist in Clinical and Sports Nutrition by the Institute of Research, Education and Management in Health, Ramiro Barcelos Street 2350, 90035-903, Porto Alegre, Rio Grande do Sul, Brazil

${ }^{2}$ Nutritionist at University Center Univates, Ramiro Barcelos Street 2350, 90035-903, Porto Alegre, Rio Grande do Sul, Brazil

${ }^{3}$ Nutritionist at Franciscan University, Master and PhD Student in Medical Sciences from the Federal University of Rio Grande do Sul, Professor at Faculty Cenecista of Bento Gonçalves, Uniritter and Estacio de Sa, Ramiro Barcelos Street 2350, 90035-903, Porto Alegre, Rio Grande do Sul, Brazil

\begin{abstract}
To assess the symptoms of premenstrual syndrome (PMS) and the nutritional status of physically active and sedentary adult women. This case-control study included 60 women, aged 18 to 35 years, recruited from two fitness centers or from an outpatient nutrition clinic. Four evaluations were conducted, on the follicular and luteal phase in two months. Questionnaires were applied to collect information about the socioeconomic condition and PMS symptoms. Weight and height were measured to calculate body mass index. Electrical bioimpedance was used to determine body composition, and food consumption was assessed using a food frequency questionnaire. The Student's test and Chisquare test were applied to compare means and proportions between the groups. The occurrence of PMS was observed in $63.3 \%$ of women in the physically active group and $86.7 \%$ of participants in the sedentary group $(p=0.074)$. Analysis of results relative to food consumption showed in the physically active group a low calorie consumption in $53.3 \%$ and $33.3 \%$ of the participants in the pre- and post-menstrual phases, respectively $(p=0.039)$. In the sedentary group, a high calorie consumption was observed in $43.3 \%$ and $23.3 \%$ of the participants in the pre- and post-menstrual phases, respectively $(p=0.007)$. The sedentary group presented carbohydrate consumption of $281.9 \pm 61.1$ grams and $252.1 \pm$ 55.9 grams in the pre- and post-menstrual phases, respectively $(p=0.001)$; increased consumption of lipids was also observed in these phases, $74.4 \pm 23.4$ grams $63.2 \pm 19.4$ grams, respectively $(p=0.001)$. The results show that the sedentary group presents an increased frequency of PMS and increased consumption of calories, carbohydrates, lipids and sodium. In the physically active group there was association between reactance and fat percentage.
\end{abstract}

Keywords: Menstrual Cycle. Premenstrual Syndrome. Physical Exercise. Nutritional Evaluation, Women.

\section{INTRODUCTION}

Women of reproductive age experience changes related to the menstrual cycle, which repeats every month with two phases, the follicular phase and the luteal phase [1]. These changes generate emotional, cognitive and physical symptoms, and these begin the week before menstruation (luteal phase) and relieve menstrual flow begins (follicular phase) [2]. In this way, the menstrual cycle is a result of coordination needs events that occur in the ovaries and beginning in the early days of menstruation [3].

This period includes hormonal, physiological and psychological alterations [1], with symptoms that may influence in a negative way in the daily activities and relationships of women [4]. When these symptoms become frequent and intense, interfering in the quality of life, a diagnosis of premenstrual syndrome (PMS) can be made [3]. According to the Brazilian Ministry of

*Address correspondence to this author at the Ramiro Barcelos Street 2350, 90035-903, Porto Alegre, Rio Grande do Sul, Brazil; Tel: +55 513359 8000; E-mail: thaisr_moreira@hotmail.com
Health, physical and emotional symptoms related to premenstrual tension (PMT) affect $70 \%$ women. Despite this, only $2 \%$ to $3 \%$ are diagnosed with PMS [5].

PMS may be caused by hormonal (progesterone, testosterone, prolactin, vasopressin, androgens), nutritional (deficit of vitamin A, B6, pyridoxine, magnesium, prostaglandin), psychosocial (social stress and social relationship), and affective disorders. The treatment of PMS includes corrective therapies, such as medications or a control of the normal ovulation cycle [6].

The effectiveness of exercise in the prevention of psychic diseases was already reported as first option for preventive treatment [7]. The strong relationship between exercising in women athletes and PMS, emphasizing the intensity of the exercises performed and the difference in performance during phases of the menstrual cycle [8].

In a study, investigating 26 women with regular menses during the two phases of the menstrual cycle, 
an association was observed between greater intake of carbohydrates and decreased physical performance during the pre-menstrual period [9]. In addition, changes in diet or excessive food consumption were related to increased water retention and increased appetite [10]. On the contrary, the amount and intensity of aerobic exercise were associated with less water retention and decreased appetite, showing that the feeding behavior and physical exercises are directly related to menstrual disorders [10].

Due to the fact there are few data on the relationship between the practice of physical exercise and PMS, the present study aimed to assess the PMS symptoms, nutritional status and food consumption of adult women practitioners of physical exercise and sedentary.

\section{METHODS}

In this prospective case-control study, women were selected for the case and control groups according participation or not in physical exercise activities on a regular basis, respectively. The survey was conducted at the Outpatient Nutrition Service of Univates University Center, in the period from June to September 2013. The study was authorized by the Univates Nutrition Course and by two gymnastics academies, and approved by the Research Ethics Committee of Univates, under Protocol n²60,099.

The sample was composed by 60 women aged between 18 and 35 years, attended at the Outpatient Nutrition Service, after signing an informed consent form. The exclusion criteria were pregnancy, lactation, pathologies resulting in edema or fluid retention, amenorrhea, use of diuretic drugs, a diagnosis of polycystic ovaries and irregular menstrual cycle. Regular physical exercise was defined as exercising during 30 to 90 minutes, at least three times per week. Women with less frequent physical activity were considered as sedentary [11]. Participants were followed-up for two months, in both phases of the menstrual cycle, totaling four evaluations per participant.

For characterization of the sample, a questionnaire was applied with the following variables: use of drugs, diagnosis of pathologies, practice and duration of physical exercise, smoking and/or alcohol consumption, use of oral contraceptive, age at menarche, number of pregnancies and regularity of the menstrual cycle. The questionnaire established by the
Diagnostic and Statistical Manual of Mental Disorders of the American Psychiatric Association - DSM IV [12] was used for the assessment of symptoms and diagnosis of PMS. In addition, a food frequency questionnaire (FFQ), validated by Ribeiro et al. [13], was also used for assessment of food quality and food consumption by the participants.

The information obtained with the FFQ was used for calculation of daily consumption of each food, according to the guidelines established by Philippi et al. and by the Brazilian Table of Food Composition $[14,15]$. These data were used for the dietary analysis, with the Dietwin $®$ Professional software, resulting in information on total energy value (TEV), percentages and quantities in grams of macronutrients and micronutrients. The formula provided by World Health Organization (WHO), as well as the activity factor, were used for estimation of recommended TEV, which was 1.64 to the case group and 1.56 for the control group [16]. Reference values for vitamins and minerals were based on the Recommended Dietary Allowances (RDA) established by the Dietary Reference Intake (DRI) [17].

Nutritional evaluation was based on the body mass index (BMI), according to the cut-off points established by the WHO [18]. For determination of the BMI, height was measured in meters with a WISO ${ }^{8}$ stadiometer and presented in meters, and body mass was measured in kilograms with an anthropometric scale WELMY®, with capacity for $150 \mathrm{~kg}$. For measurements, participants wear a light coat, were barefooted and in standing position. The percentage of body fat, body water, lean body mass and reactance were measured with use of a Bioelectrical Impedance Analysis (BIA) analyzer, Biodynamics $₫$ model 310 .

The following criteria were to classify individuals according to body fat percentages: thin $<13 \%$, optimal $13 \%$ to $23 \%$, mild $24 \%$ to $27 \%$, adiposity $28 \%$ to $32 \%$ and obesity $>32 \%$ [19]. The average value of $50 \%$ of the body mass was used to determine the amount of body water [20]. The participants were oriented on how to prepare for the BIA measurement, according to Silva-Filho et al. [21].

For statistical analysis, the continuous variables were described as mean and standard deviation. Categorical variables were described as absolute and relative frequencies. The paired Student's t-test or the Wilcoxon test were used for the evaluation of food 
consumption before and after the menstrual period. The association between categorical variables was evaluated by the Pearson's Chi-square test. Averages were compared between the groups with the Student's t-test. The association between continuous and ordinal variables was assessed by the Pearson and Spearman correlation coefficients, respectively. The significance level used was $5 \%(p \leq 0.05)$ and the analyses were performed in the software Statistical Package for the Social Sciences (SPSS) version 18.0.

\section{RESULTS}

Table 1 presents the baseline characteristics of the case and control groups. No statistically significant differences were observed between the groups. However, a higher frequency of PMS was observed in the sedentary control group, when compared to the exercise case group.

Results on the evaluation of the nutritional status and body composition are presented in Table 2 . No

Table 1: Characterization of the Sample

\begin{tabular}{|c|c|c|c|}
\hline Variables & $\begin{array}{l}\text { Physical practice group } \\
\qquad(n=30)\end{array}$ & $\begin{array}{l}\text { Sedentary group } \\
\qquad(n=30)\end{array}$ & $\mathbf{p}$ \\
\hline Age (years) - mean \pm SD & $25.9 \pm 4.0$ & $25.2 \pm 2.8$ & $0.412^{*}$ \\
\hline Drugs $-\mathrm{n}(\%)$ & & & $0.671^{* *}$ \\
\hline Yes & $4(13.3)$ & $2(6.7)$ & \\
\hline No & $26(86.7)$ & $28(93.3)$ & \\
\hline Diagnosis of pathologies - $n(\%)$ & & & $0.369^{* *}$ \\
\hline None & $26(86.7)$ & $30(100)$ & \\
\hline Gastritis & $1(3.3)$ & $0(0.0)$ & \\
\hline Vitiligo & $1(3.3)$ & $0(0.0)$ & \\
\hline Lupus & $1(3.3)$ & $0(0.0)$ & \\
\hline Binge eating disorder & $1(3.3)$ & $0(0.0)$ & \\
\hline Smoking/Alcoholism-n(\%) & & & $1.000^{* *}$ \\
\hline Yes & $2(6.7)$ & $1(3.3)$ & \\
\hline No & $28(93.3)$ & $29(96.7)$ & \\
\hline Age at menarche (years) - mean \pm SD & $12.6 \pm 1.3$ & $12.8 \pm 1.2$ & $0.476^{*}$ \\
\hline Use of oral contraceptive $-\mathrm{n}(\%)$ & & & $0.671^{* *}$ \\
\hline Yes & $28(93.3)$ & $26(86.7)$ & \\
\hline No & $2(6.7)$ & $4(13.3)$ & \\
\hline Regular menstrual cycle- $\mathrm{n}(\%)$ & & & $1.000^{* *}$ \\
\hline Yes & $30(100)$ & $29(96.7)$ & \\
\hline No & $0(0.0)$ & $0(0.0)$ & \\
\hline School level - n(\%) & & & $0.237^{* *}$ \\
\hline Complete high school & $3(10.0)$ & $0(0.0)$ & \\
\hline College & $27(90.0)$ & $30(100)$ & \\
\hline Marital status-n(\%) & & & $0.543^{* *}$ \\
\hline Single & $26(86.7)$ & $25(83.3)$ & \\
\hline Married & $3(10.0)$ & $2(6.7)$ & \\
\hline Stable union & $1(3.3)$ & $3(10.0)$ & \\
\hline PMS - n(\%) & & & $0.074^{* *}$ \\
\hline Yes & $19(63.3)$ & $26(86.7)$ & \\
\hline No & $11(36.7)$ & $4(13.3)$ & \\
\hline
\end{tabular}

*Student's t-test; **Fisher exact test; ***Pearson's chi-square test. $\mathrm{SD}=$ standard deviation, $\mathrm{PMS}=$ premenstrual syndrome. 
Table 2: Comparison of Anthropometric Data and Body Composition

\begin{tabular}{|c|c|c|c|c|c|c|}
\hline \multirow[t]{2}{*}{ Variables } & \multicolumn{3}{|c|}{$\begin{array}{l}\text { Physical practice group } \\
\qquad(n=30)\end{array}$} & \multicolumn{3}{|c|}{$\begin{array}{l}\text { Sedentary group } \\
\qquad(n=30)\end{array}$} \\
\hline & Pre-menstrual & $\begin{array}{c}\text { Post- } \\
\text { menstrual }\end{array}$ & p & $\begin{array}{c}\text { Pre- } \\
\text { menstrual }\end{array}$ & $\begin{array}{c}\text { Post- } \\
\text { menstrual }\end{array}$ & p \\
\hline Weight $(\mathrm{kg})-$ mean $\pm \mathrm{SD}$ & $59.0 \pm 6.4$ & $58.8 \pm 6.6$ & 0.312 & $58.2 \pm 10.7$ & $58.1 \pm 10.7$ & $0.506^{*}$ \\
\hline $\mathrm{BMI}\left(\mathrm{kg} / \mathrm{m}^{2}\right)-$ mean $\pm \mathrm{SD}$ & $22.0 \pm 1.9$ & $21.9 \pm 1.9$ & 0.327 & $21.7 \pm 3.5$ & $21.7 \pm 3.5$ & $0.433^{*}$ \\
\hline Classification of BMI $-\mathrm{n}(\%)$ & & & 1.000 & & & $0.317^{\star *}$ \\
\hline Malnourished & $0(0.0)$ & $0(0.0)$ & & $3(10.0)$ & $4(13.3)$ & \\
\hline Eutrophic & $28(93.3)$ & $28(93.3)$ & & $23(76.7)$ & $22(73.3)$ & \\
\hline Overweight & $2(6.7)$ & $2(6.7)$ & & $2(6.7)$ & $2(6.7)$ & \\
\hline Obesity & $0(0.0)$ & $0(0.0)$ & & $2(6.7)$ & $2(6.7)$ & \\
\hline$\%$ BF adequacy - n(\%) & & & 0.257 & & & $0.218^{* *}$ \\
\hline Optimal & $22(73.3)$ & $20(66.7)$ & & $18(60.0)$ & $22(73.3)$ & \\
\hline Mild & $7(23.3)$ & $8(26.7)$ & & $7(23.3)$ & $3(10.0)$ & \\
\hline Adiposity & $1(3.3)$ & $2(6.7)$ & & $4(13.3)$ & $5(16.7)$ & \\
\hline Obesity & $0(0.0)$ & $0(0.0)$ & & $1(3.3)$ & $0(0.0)$ & \\
\hline Lean body mass $(\mathrm{kg})-$ mean $\pm \mathrm{SD}$ & $45.8 \pm 4.7$ & $45.5 \pm 4.8$ & 0.159 & $44.6 \pm 5.9$ & $45.3 \pm 6.6$ & $0.080^{*}$ \\
\hline Reactance (ohms) - mean \pm SD & $69.9 \pm 9.1$ & $71.7 \pm 14.1$ & 0.469 & $71.3 \pm 14.1$ & $68.6 \pm 9.8$ & $0.188^{*}$ \\
\hline Adequate hydration - $\mathrm{n}(\%)$ & & & 0.655 & & & $0.705^{* *}$ \\
\hline Adequate & $23(76.7)$ & $22(73.3)$ & & $18(60.0)$ & $17(56.7)$ & \\
\hline Above & $7(23.3)$ & $8(26.7)$ & & $12(40.0)$ & $13(43.3)$ & \\
\hline
\end{tabular}

*Student's t-test; **Fisher exact test; ${ }^{* * *}$ Pearson's chi-square test.

$\mathrm{SD}=$ standard deviation, $\mathrm{PMS}=$ premenstrual syndrome, $\mathrm{BF}=$ body fat.

statistically significant differences were observed between the case and control groups, in pre and postmenstrual periods.

Table 3 presents the results on the consumption of macronutrients in the pre and postmenstrual periods in both groups. Women in the sedentary group presented a statistically significant reduction in TEV $(p=0.007)$ and in the consumption of carbohydrates $(g)(p<0.001)$ and lipids $(g)(p<0.001)$, in the postmenstrual period.

Results on the consumption of micronutrients in the pre and postmenstrual periods in both groups can be seen in Table 4. Women in the sedentary group presented significantly lower consumption of sodium $(p=0.002)$ and vitamin $D \quad(p=0.021)$, in the postmenstrual period.

The relationship between reactance and postmenstrual body fat percentage is presented in Figure 1. A statistically significant direct association was observed between these variables in the case group ( $r=0.381 ; p=0.038)$. In this group, an association was observed in the premenstrual period $(r=0.359$; $p=0.051)$. No significant association was seen in the sedentary control group $(r=0.041 ; p=0.831)$.

The sodium consumption of participants with PMS in both groups, in the pre and postmenstrual periods, is presented in Figure 2 in relation to the adequate intake. A significant reduction in sodium intake $(p=0.022)$ was observed in the sedentary group in the postmenstrual period.

\section{DISCUSSION}

A considerable but not statistically significant difference was observed in the frequency of PMS in the two groups $-86.7 \%$ in the sedentary group and $63.3 \%$ in the exercise group. This result suggests a possible relationship between the practice of physical exercise and premenstrual symptoms or PMS itself, as already observed in other studies [22-25].

A recent review analyzed four intervention studies investigating the effects of physical exercises on PMS. In spite of small samples and low methodological quality, all studies showed a reduction in PMS and its symptoms after the introduction of physical exercise 
Table 3: Comparison of the Dietary Intake of Macronutrients in Pre. and Post-Menstrual Periods

\begin{tabular}{|c|c|c|c|c|c|c|}
\hline \multirow{2}{*}{ Variables } & \multicolumn{3}{|c|}{$\begin{array}{l}\text { Physical practice group } \\
\qquad(n=30)\end{array}$} & \multicolumn{3}{|c|}{$\begin{array}{l}\text { Sedentary group } \\
\qquad(n=30)\end{array}$} \\
\hline & Pre-menstrual & $\begin{array}{c}\text { Post- } \\
\text { menstrual }\end{array}$ & $\mathbf{p}$ & $\begin{array}{c}\text { Pre- } \\
\text { menstrual }\end{array}$ & Post-menstrual & p \\
\hline VET adequacy $-n(\%)$ & & & 0.039 & & & $0.007^{\star *}$ \\
\hline Below & $16(53.3)$ & $10(33.3)$ & & $10(33.3)$ & $13(43.3)$ & \\
\hline Above & $5(16.7)$ & $8(26.7)$ & & $13(43.3)$ & $7(23.3)$ & \\
\hline $\mathrm{CHO}(\mathrm{g})-$ mean $\pm \mathrm{SD}$ & $250.6 \pm 58.7$ & $269.0 \pm 60.1$ & 0.149 & $281.9 \pm 61.1$ & $252.1 \pm 55.9$ & $<0.001^{*}$ \\
\hline $\mathrm{CHO}$ adequacy $-\mathrm{n}(\%)$ & & & 0.346 & & & $0.083^{* *}$ \\
\hline Below & $22(73.3)$ & $19(63.3)$ & & $14(46.7)$ & $17(56.7)$ & \\
\hline PTN $(g)-$ mean \pm SD & $105.2 \pm 25.4$ & $105.2 \pm 21.6$ & 0.988 & $103.3 \pm 25.6$ & $97.6 \pm 24.2$ & $0.171^{*}$ \\
\hline PTN adequacy $-n(\%)$ & & & 0.322 & & & $0.438^{\star *}$ \\
\hline Below & $10(33.3)$ & $14(46.7)$ & & $13(43.3)$ & $14(46.7)$ & \\
\hline Adequate & $14(46.7)$ & $11(36.7)$ & & $8(26.7)$ & $10(33.3)$ & \\
\hline Above & $6(20.0)$ & $5(16.7)$ & & $9(30.0)$ & $6(20.0)$ & \\
\hline LIP $(g)-$ mean \pm SD & $68.7 \pm 28.2$ & $70.0 \pm 23.8$ & 0.642 & $74.4 \pm 23.4$ & $63.2 \pm 19.4$ & $<0.001^{*}$ \\
\hline LIP adequacy $-n(\%)$ & & & 0.564 & & & $0.016^{* *}$ \\
\hline Below & $17(56.7)$ & $14(46.7)$ & & $11(36.7)$ & $16(53.3)$ & \\
\hline Above & $16(53.3)$ & $17(56.7)$ & & $14(46.7)$ & $11(36.7)$ & \\
\hline Fibers $(\mathrm{g})-$ mean $\pm \mathrm{SD}$ & $29.7 \pm 13.0$ & $30.3 \pm 10.1$ & 0.748 & $31.0 \pm 9.6$ & $29.8 \pm 8.8$ & $0.224^{*}$ \\
\hline Fibers adequacy $-\mathrm{n}(\%)$ & & & 1.000 & & & $1.000^{\star *}$ \\
\hline Below & $6(20.7)$ & $7(23.3)$ & & $7(23.3)$ & $5(16.7)$ & \\
\hline Adequate & $7(24.1)$ & $7(23.3)$ & & $4(13.3)$ & $8(26.7)$ & \\
\hline Above & $16(55.2)$ & $16(53.3)$ & & $19(63.3)$ & $17(56.7)$ & \\
\hline
\end{tabular}

*Student's t-test; ${ }^{* *}$ Fisher exact test; ${ }^{* * *}$ Pearson's chi-square test.

$\mathrm{TEV}=$ total energy value, $\mathrm{CHO}=$ carbohydrates, $\mathrm{PTN}=$ proteins, $\mathrm{LIP}=$ lipids

[22]. A similar study was conducted with 40 sedentary women aged between 18 and 25 years. The sample was divided into a control group and a group with introduction of physical exercise three times a week. The impact of eight weeks of physical exercise was positive, with reduction of premenstrual symptoms after the start of the intervention, compared to the previous period and to the control group [23,24]. A similar study showed significant reduction in the PMS symptoms after three weeks of physical exercise, without a difference between the study groups [25].

The only difference observed between participants with or without a diagnosis of PMS was a reduction in the consumption of lipids and sodium in sedentary PMS women. A study with Japanese women showed no association between consumption of soy and 
Table 4: Comparison of the Dietary Intake of Micronutrients in the Pre- and Post-Menstrual Periods

\begin{tabular}{|c|c|c|c|c|c|c|}
\hline \multirow[t]{2}{*}{ Variables } & \multicolumn{3}{|c|}{$\begin{array}{l}\text { Physical practice group } \\
\qquad(n=30)\end{array}$} & \multicolumn{3}{|c|}{$\begin{array}{l}\text { Sedentary group } \\
\qquad(n=30)\end{array}$} \\
\hline & Pre-menstrual & Post-menstrual & $\mathbf{p}$ & Pre-menstrual & Post-menstrual & $\mathbf{p}$ \\
\hline Below & $15(50.0)$ & $16(53.3)$ & & $18(60.0)$ & $22(73.3)$ & \\
\hline Adequate & $11(36.7)$ & $9(30.0)$ & & $7(23.3)$ & $5(16.7)$ & \\
\hline Fe adequacy $-n(\%)$ & & & 0.490 & & & $0.791^{\star \star}$ \\
\hline Below & $23(76.7)$ & $21(70.0)$ & & $21(70.0)$ & $20(66.7)$ & \\
\hline Adequate & $5(16.7)$ & $6(20.0)$ & & $3(10.0)$ & $6(20.0)$ & \\
\hline Above & $2(6.7)$ & $3(10.0)$ & & $6(20.0)$ & $4(13.3)$ & \\
\hline Above & $12(40.0)$ & $12(40.0)$ & & $20(66.7)$ & $12(40.0)$ & \\
\hline $\mathrm{K}$ adequacy $-\mathrm{n}(\%)$ & & & 0.317 & & & $1.000^{\star \star}$ \\
\hline Below & $30(100)$ & $29(96.7)$ & & $30(100)$ & $30(100)$ & \\
\hline Above & $0(0.0)$ & $1(3.3)$ & & $0(0.0)$ & $0(0.0)$ & \\
\hline Vit. A adequacy - n(\%) & & & 0.420 & & & $0.783^{* \star}$ \\
\hline Below & $10(33.3)$ & $9(30.0)$ & & $9(30.0)$ & $11(36.7)$ & \\
\hline Adequate & $2(6.7)$ & $0(0.0)$ & & $3(10.0)$ & $0(0.0)$ & \\
\hline Above & $18(60.0)$ & $21(70.0)$ & & $18(60.0)$ & $19(63.3)$ & \\
\hline Adequate & $2(6.7)$ & $5(16.7)$ & & $2(6.7)$ & $4(13.3)$ & \\
\hline Above & $20(66.7)$ & $19(63.3)$ & & $22(73.3)$ & $21(70.0)$ & \\
\hline $\mathrm{B} 6$ adequacy $-\mathrm{n}(\%)$ & & & 0.527 & & & $0.705^{\star \star}$ \\
\hline Below & $25(83.3)$ & $23(76.7)$ & & $25(83.3)$ & $23(76.7)$ & \\
\hline Adequate & $5(16.7)$ & $7(23.3)$ & & $4(13.3)$ & $7(23.3)$ & \\
\hline Above & $0(0.0)$ & $0(0.0)$ & & $1(3.3)$ & $0(0.0)$ & \\
\hline Mg adequacy $-\mathrm{n}(\%)$ & & & 0.710 & & & $1.000^{\star \star}$ \\
\hline Below & $23(76.7)$ & $25(83.3)$ & & $27(90.0)$ & $27(90.0)$ & \\
\hline Adequate & $5(16.7)$ & $3(10.0)$ & & $2(6.7)$ & $2(6.7)$ & \\
\hline Above & $2(6.7)$ & $2(6.7)$ & & $1(3.3)$ & $1(3.3)$ & \\
\hline
\end{tabular}

*Student's t-test; **Fisher exact test; ${ }^{* * *}$ Pearson's chi-square test.

$\mathrm{Ca}=$ calcium, $\mathrm{Fe}=$ iron, $\mathrm{Na}=$ sodium, $\mathrm{K}=$ potassium, Vit. $\mathrm{A}=$ vitamin $\mathrm{A}, \mathrm{Vit} . \mathrm{D}=$ vitamin $\mathrm{D}, \mathrm{Vit} . \mathrm{C}=$ vitamin $\mathrm{C}, \mathrm{B} 6=$ vitamin $\mathrm{B} 6, \mathrm{Mg}=$ magnesium.

isoflavones and premenstrual symptoms. However, a significant relationship was observed between these symptoms and the intake of total fats, saturated and monounsaturated [26].
Another study investigated, in a sample of 71 women, the relationship between the level of physical activity and the incidence of PMS. They found that higher levels of physical activity were associated with a 


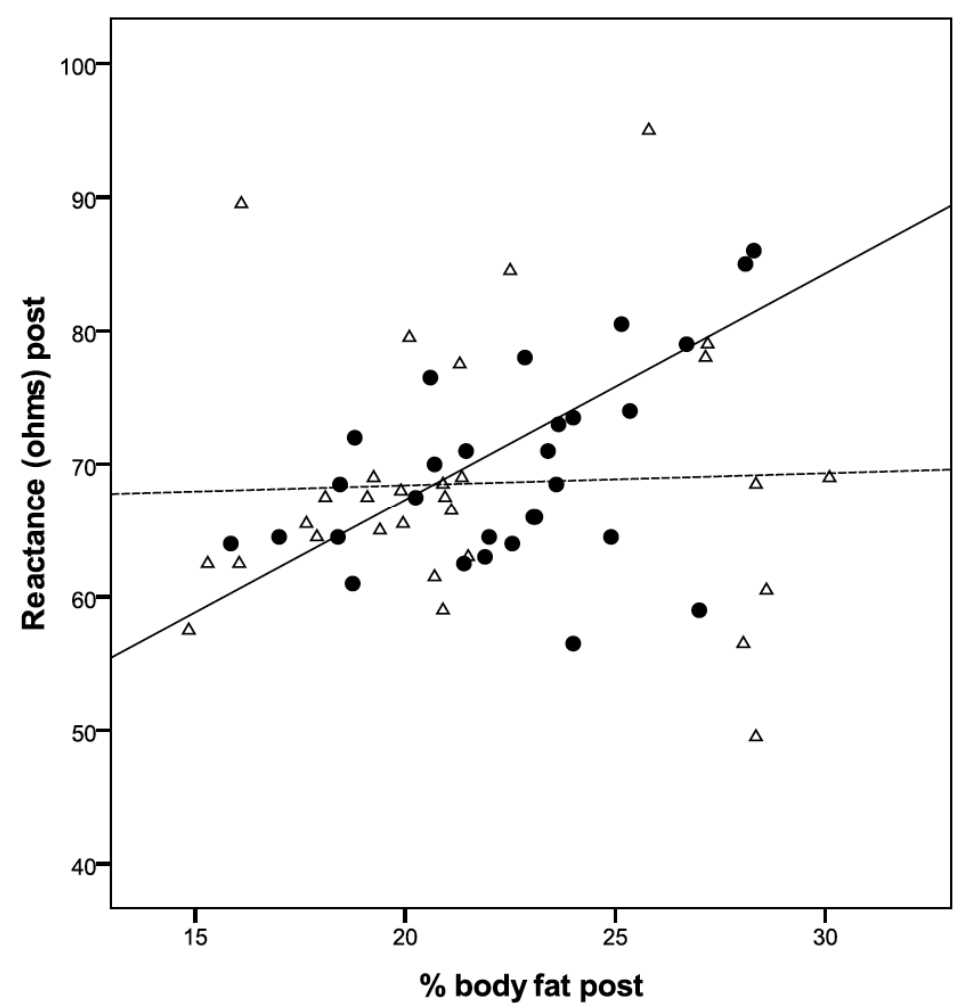

Physical practice

yes

$\triangle$ no

$\rightarrow$ yes

-..no no

$\%$ body fat post

Figure 1: Relationship between reactance and body fat percentage in the post-menstrual period.

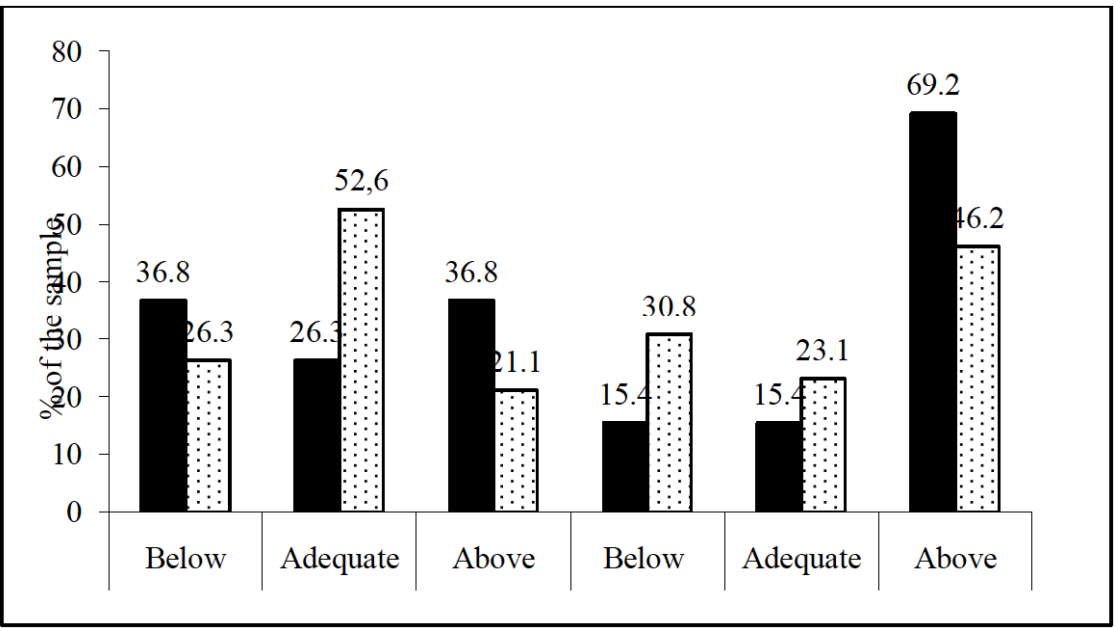

Figure 2: Association between sodium intake in the pre- and post-menstrual periods according to physical activity, on PMS participants.

reduced the incidence of PMS. Women diagnosed with PMS had a lower level of physical activity than healthy women. These results show that the practice of physical exercise can help with the prevention and/or treatment of PMS [27]. A similar result was found in the present study, with a higher intake of lipids by sedentary PMS women in the premenstrual period.

Body weight, BMI, body fat percentage and lean mass presented similar values between the groups, and none of the anthropometry and body composition variables showed a statistically significant difference between the phases of the menstrual cycle. Different results were observed in a study conducted with 40 college women, with higher levels of fat percentage $(p=0.019)$ and waist circumference $(p=0.021)$ in the luteal phase than in the follicular phase of the menstrual cycle [28]. In the present work, BMI results showed that $93.3 \%$ of the exercising participants were eutrophic in the two periods, compared to $76.7 \%$ and $73.3 \%$ in the sedentary group in pre and postmenstrual periods, respectively. Similarly, Oliveira et al. found no 
significant variations in BMI among the menstrual periods [28].

The investigation of the relationship of reactance with BMI, body fat percentage and lean mass showed only one direct association, between body fat percentage and reactance, in exercising women in the postmenstrual period. In the premenstrual period, this association was borderline. These results support the use of the BIA method for evaluation of the body composition [26]. A study demonstrated that the greater the amount of body water, the more easily the electric current flows through the tissues, i.e. the reactance to the electrical current flow is increased in individuals with high amount of fat, which is a poor electrical conductor due to the small amount of water [29].

The consumption of calories was significantly increased in exercising women in the postmenstrual period. It is probable that this increase has no relationship with the premenstrual period and its symptoms. On the other hand, the significant reduction of TEV, carbohydrates, lipids, sodium and vitamin D in sedentary women in the postmenstrual period may indicate a possible relationship between the practice of physical exercise and dietary intake in the premenstrual period. Similar results were found in a study with 144 women with PMS, accompanied during two cycles and evaluated through food recall. Nutrient analyses showed a significant increase in total energy, carbohydrates and lipids in the premenstrual, when compared to postmenstrual period. On the other hand, there was a decrease in the amount of protein in the premenstrual period $[30,31]$.

Larger amounts of carbohydrates and lipids in women with PMS in the luteal phase of the menstrual cycle were also observed in another (pilot) study, which evaluated possible differences in sensitivity to insulin, food consumption and food cravings in PMS women during the luteal and follicular phases of the menstrual cycle. No statistically significant difference was found in insulin sensitivity and food consumption, but in all cases the amount of macronutrients was slightly larger in the luteal phase [32].

Tucci et al. investigated the relationship of PMS to oral contraceptive methods and the effects on the choice of food during the two phases of the menstrual cycle. The results showed that participants that did not use oral contraceptives had a greater caloric intake of sweet foods in the luteal phase, while in the remaining participants this increased intake was in the follicular phase [33]. In the present work, most participants used oral contraceptive, so that it was not possible to search for this relationship. However, considering sweet foods as carbohydrates, similar results were observed.

A study with similar methodology investigated a possible relationship of the consumption of vitamin $D$ and calcium with PMS and its symptoms in women aged 27 to 44 years. The results showed that high intake of calcium and vitamin $D$ can reduce the risk of PMS. Since these nutrients reduce the risk of osteoporosis and some types of cancer, their intake may be recommended also for younger women [34]. In the present study, a significant reduction in the consumption of vitamin $D$ was observed in sedentary women in the postmenstrual period, but no associations were found with premenstrual symptoms.

A case-control study with 3025 women assessed the consumption of vitamins through a food frequency questionnaire. The results showed that lower incidences of PMS were associated with high consumption of foods rich in thiamin and riboflavin, but not with the ingestion of vitamin B through supplements [35]. In the present study, no significant differences relative to the consumption of these nutrients were observed between groups or between periods of the menstrual cycle.

In addition to all these information, Kim et al. stated that any improvement in lifestyle, such as physical exercises, self-care and a balanced diet, is effective in reducing the symptoms of PMS [36]. Our results support this conclusion, since the physical practice group had more adequate food consumption in the premenstrual phase than the sedentary group.

This study has some limitations, such as the followup time of participants, which was two months and could have been longer. However, a literature review showed only cross-sectional studies on this topic. Furthermore, the literature is scarce in studies on the relationship between the diagnosis of PMS and the practice of physical exercise.

\section{CONCLUSIONS}

No differences were observed between the study groups in relation to the diagnosis of PMS or body composition. In the assessment of the dietary intake, a reduction of TEV, carbohydrates, lipids, sodium and vitamin $D$ was found in the sedentary group in the 
postmenstrual period. In the physical practice group, no modifications were observed in the consumption of nutrients included in this study, in any of the menstrual periods.

\section{REFERENCES}

[1] Braz L, de Lima JRP. Pre and post-menstrual aerobic assessment. Revista Brasileira de Ciências da Saúde 2010; 6(15).

[2] Silva SMCS, Silva BFC, Farina BV, Spinoza D, Breda SM. The influence of premenstrual syndrome (PMS) on emotional symptoms and food intake. Nutrire: rev Soc Bras Alim Nutr Abril 2012; São Paulo, SP, 37(1): 13-21.

[3] Aun FV, Pinheiro MN. Alimentação e Síndrome de tensão pré-menstrual. Universidade Presbiteriana Mackenzie 2011; 1-13.

[4] Valadares GC, Ferreira LV, Correa Filho H, Romano-Silva MA. Transtorno disfórico pré-menstrual revisão - conceito, história, epidemiologia e etiologia. Rev Psiq Clín 2006; 33(3): 5-11.

[5] Silva dos Santos LA, et al. Estado nutricional e consumo alimentar de mulheres jovens na fase lútea e folicular do ciclo menstrual. Rev Nutr Campinas Abr 2011; 24(2).

[6] Muramatsu CH, Vieira OCS, Simões CC, Katayama DA, Nakagawa $\mathrm{FH}$. Consequências da síndrome de tensão prémentrual na vida da mulher. Rev Esc Enferm USP 2001; 205-213.

https://doi.org/10.1590/S0080-62342001000300002

[7] Byrne A, Byrne DG. The effect of exercise on depression, anxiety and other mood states: a review. Journal of Psychosomatic Research 1993; 37(6): 565-574. https://doi.org/10.1016/0022-3999(93)90050-P

[8] Gaion, PA, Vieira LF. Prevalência de síndrome pré-menstrual em atletas. Rev Bras Med Esporte 2010; 16(1): 24-8. https://doi.org/10.1590/S1517-86922010000100004

[9] Sadler C, et al. Lifestyle factors, hormonal contraception, and premenstrual symptoms: the United Kingdom Southampton Women's Survey. Journal of Women's Health 2010; 19(3): 391-396.

https://doi.org/10.1089/jwh.2008.1210

[10] Johnson WG, Carr-Nangle, Robecca E, Bergeron, Kimberly C. Macronutrient intake, eating habits, and exercise as moderators of menstrual distress in healthy women. Psychosomatic Medicine 1995; 57(4): 324-330. https://doi.org/10.1097/00006842-199507000-00003

[11] Leitão $\mathrm{MB}$, et al. Posicionamento oficial da Sociedade Brasileira de Medicina do Esporte: atividade física e saúde na mulher. Rev. Bras. Medicina do Esporte 2000; 6(6): 215220.

[12] First MB. Premenstrual dysphoric disorder. In: ed. Diagnostic and statistical manual of mental disorders: DSM-IV-TR. Washington: American Psychiatric Association 2000; 4: 771.

[13] Ribeiro AG, Sávio KEO, Rodrigues ML, Ferreirinha C, Costa TH, Schmitz, BS. Validação de um questionário de freqüência de consumo alimentar para população adulta. Rev Nutr 2006; 19(5).

[14] Philippi ST, Latterza AR, Cruz ATR, Ribeiro LC. Pirâmide Alimentar Adaptada: guia para escolha dos alimentos. Rev Nutr 1999; 12(1): 65-80. https://doi.org/10.1590/S1415-52731999000100006

[15] Lima DM, et al. Tabela brasileira de composição de alimentos-TACO. NEPA-Unicamp 2011.

[16] World Health Organization (WHO). Energy and protein requirements: Report of a joint $\mathrm{FAO/WHO/UNU}$ expert consultation. WHO Technical Report Series No. 724. Geneva 1985. Disponível em: extranet.who.int.
Otten JJ, Hellwig JP, Meyers LD. DRI, dietary reference intakes: the essential guide to nutrient requirements. National Academies Press 2006.

[18] World Health Organization (WHO). Physical Satatus: the use and interpretation of Anthopometry. Technical Reports Series, 854 Genebra 1995. Disponivel em: extranet.who.int.

[19] Nieman DC, et al. Fitness and sports medicine: an introduction. Bull Publishing Company 1990; 23: 583.

[20] Schoeller AD, Hydrometry IN, Heymsfield SB, Lohman TG, Wang Z, Going SB. Human body composition. 2. ed. Champaign: Human Kinetics 2005.

[21] Silva-Filho AA, Werustsky CA, Ribas DF, Spolidoro J, Marchini JS. Utilização da Bioimpedância para Avaliação da Massa Corpórea. Associação Médica Brasileira e Conselho Federal de Medicina: Projeto Diretrizes 2009.

[22] Daley A. Exercise and premenstrual symptomatology: a comprehensive review. Journal of Women's Health 2009; 18(6): 895-899. https://doi.org/10.1089/jwh.2008.1098

[23] Samadi Z, Taghian F, Valiani M. The effects of 8 weeks of regular aerobic exercise on the symptoms of premenstrual syndrome in non athlete girls. Iranian Journal of Nursing and Midwifery Research 2013; (18)1.

[24] Ghanbari Z, Manshavi FD, Jafarabadi M. The effect of three months regular aerobic exercise on premenstrual syndrome. Journal of Family and Reproductive Health 2008; 2(4).

[25] Tonekaboni MM, Peeri M, Azarbayjani MA. Effect of Two Intensity of Aerobic Exercise on Clinical Symptoms of Premenstrual Syndrome in Fertile Women. World Applied Sciences Journal 2012; 19(3): 295-301.

[26] Nagata C, et al. Soy, fat and other dietary factors in relation to premenstrual symptoms in Japanese women. International Journal of Obstetrics \& Gynaecology 2004; 111(6): 594-599. https://doi.org/10.1111/j.1471-0528.2004.00130.x

[27] Teixeira ALS, Oliveira ECM, Dias MRC. Relação entre o nível de atividade física e a incidência da síndrome prémenstrual. Rev. bras. ginecol. Obstet 2013; 35(5): 210-214. https://doi.org/10.1590/S0100-72032013000500004

[28] De Oliveira DR, et al. Síndrome pré-menstrual e aspectos relacionados à antropometria e ao comportamento alimentar. O Mundo da Saúde 2013; 37(3): 280-287.

[29] Carvalho ABR, Pires Neto CS. Body composition by underwater weighing and bioelectrical impedance methods in college students. Rev Bras Cineantropom Desempenho Hum. 1999; 1(1): 18-23.

[30] Cross GB, et al. Changes in nutrient intake during the menstrual cycle of overweight women with premenstrual syndrome. British Journal of Nutrition 2001; 85(4): 475-482. https://doi.org/10.1079/BJN2000283

[31] Mcneil J, Doucet E. Possible factors for altered energy balance across the menstrual cycle: a closer look at the severity of PMS, reward driven behaviors and leptin variations. European Journal of Obstetrics \& Gynecology and Reproductive Biology 2012; 163(1): 5-10. https://doi.org/10.1016/i.ejogrb.2012.03.008

[32] Trout KK, et al. Insulin sensitivity, food intake, and cravings with premenstrual syndrome: A pilot study. Journal of Women's Health 2008; 17(4): 657-665.

https://doi.org/10.1089/jwh.2007.0594

[33] Tucci A, et al. Influencia del síndrome premenstrual y el uso de anticonceptivos orales en la selección de alimentos durante las fases folicular y lútea del ciclo menstrual. Endocrinologia y Nutricion 2009; 56(4): 170-175. https://doi.org/10.1016/S1575-0922(09)70981-7

[34] Bertone-Johnson ER, Hankinson SE, Bendich A, Johnson SR, Willett WC, Manson JE. Calcium and vitamin D intake and risk of incident premenstrual syndrome. Archives of Internal Medicine 2005; 165(11): 1246 https://doi.org/10.1001/archinte.165.11.1246 
[35] Chocano-Bedoya PO, et al. Dietary B vitamin intake and incident premenstrual syndrome. The American Journal of Clinical Nutrition 2011; 93(5): 1080-1086.

https://doi.org/10.3945/ajcn.110.009530
[36] Kim HW, et al. Intake of dietary soy isoflavones in relation to perimenstrual symptoms of Korean women living in the USA. Nursing \& Health Sciences 2006; 8(2): 108-113. https://doi.org/10.1111/j.1442-2018.2006.00270.x

Received on 10-10-2016

Accepted on 11-11-2016

Published on 01-02-2017

DOI: http://dx.doi.org/10.6000/1929-5634.2016.05.04.2 